\title{
Editorial: Landslide Hazard in a Changing Environment
}

\author{
Davide Tiranti* and Roberto Cremonini \\ Department of Natural and Environmental Risks, Regional Agency for Environmental Protection of Piemonte, Turin, Italy
}

Keywords: climate change impacts, landslide early warning system, landslide modeling, landslide hazard assessment, debris flow, flash flood, glacial lake overbust flood

\section{Editorial on the Research Topic}

\section{Landslide Hazard in a Changing Environment}

Landslides are one of the most common natural disasters in the world causing large economic losses and casualties. Their impacts are increasing globally due to rapid development, deforestation and urbanization. According to the Emergency Events Database at Université Catholique de Louvain (UCL) - CRED, from 2008 to 2017 (OFDA/CRED, 2018), landslides has been responsible for 10,338 deaths worldwide, with more than 3 million citizens affected and more than US\$ 2.7 billion economic losses. Even in the absence of fatalities, landslides and floods have significant socio-economic impacts. These include the severance of access to and from relatively remote communities for services and markets for goods; employment, health and educational opportunities; and social activities. Recently, a series of debris flows occurred in southern California, US, on January 2018 causing 21 deaths and economic losses for more than US\$ 207 million, and landslides caused by heavy rain killed 32 people in Ethiopia in May 2018.

Cruden and Varnes (1996) define landslides as movements of a mass of rock, debris or earth down the slope. Hungr et al. (2014) classified landslides based on failure mechanisms and involved material. Other relevant landslide classifications are related to landslide velocity (Cruden and Varnes, 1996) and size (Fell, 1994) as expression of phenomenal magnitude or related to the triggering factors, like earthquakes or rainfall (Rodríguez et al., 1999; Katsura et al., 2008; Baum and Godt, 2010; Havenith et al., 2016; Calvello, 2017).

During the last decades, climate change has affected the stability of natural and engineered slopes at different temporal and geographical scales (Seneviratne et al., 2012). Several studies demonstrated the impact of climate change on landslide occurrence and investigated future scenarios according to climate model projections (Stoffel et al., 2014, Gariano and Guzzetti, 2016). The type, extent, magnitude and direction of the changes in the stability conditions, and on the location, abundance, activity and frequency of landslides as a consequence of the projected climate changes is under debate (Gariano and Guzzetti, 2016).

In this research topic, Zumpano et al. present two case studies in low-density populated areas in the southern Apennine (Italy) and Romania. In these areas, the main productive activities are based on agricultural and pastoral resources, evaluating the potential economic loss trends in rural areas, according to future scenarios by 2050. Esposito et al. show an interesting analysis of increasing flash flood frequency linked to climate changes in urbanized coastline in southern Italy, during 1970-2014.

Developing landslide hazard/risk modeling applications is a complex task that involves geomorphology, hydrology, geoengineering and statistics (Hungr et al., 1984; Glade, 2005; Fuchs et al., 2008; Bhatt et al., 2013). To properly define hazard/risk scenarios, it is mandatory to characterize and to model the triggering causes and the propagational and deposition pattern of mobilized material. In this research topic, Gregoretti et al. describe the back analysis of the 
debris flow that occurred in 2015 at Rio Secco Creek (northeastern Italy), demonstrating that the proposed rainfall-runoff model can reconstruct the triggering factors and the process evolution (propagation and deposition). Boreggio et al. show that the most relevant input in simulations of debris flow routing is the Digital Terrain Model (DEM) with appropriate resolution: several interpolation methods to derive DEM in complex orography are investigated by a GIS framework. Effects of different gridding techniques are also evaluated on modeling of debris flow routing.

Landslide hazard assessment is a relevant step toward landslide hazard and risk management. Pardeshi et al. (2013) provide a comprehensive overview of current techniques in this field of research. In this research topic, Tiranti et al. propose an integrated approach in an Alpine environment (north-western Italy), demonstrating that the comprehensive hazard scenario is evaluated by incorporating the source areas' distribution and characteristics, the actual connection to main channel, estimated by the Connectivity Index, propagation and deposition modeling operated by a 3D Cellular Automata algorithm. Frey et al. describe a study on Quillcay catchment in the Cordillera Blanca, Perú, presenting a scenario-based multi-source glacial lake over burst flood. Beside technical aspects, the study gives special attention to approval and dissemination of hazards information given the complex institutional context.

In 2009, the United Nations Office for Disaster Risk Reduction (UNISDR, 2009) defined an early warning system (EWS) as "a set of capacities needed to generate and disseminate timely and meaningful warning information to enable individual, communities and organizations threatened by a hazard to act appropriately and in sufficient time to reduce the possibility of harm or loss". There are many operational EWSs currently

\section{REFERENCES}

Baum, R. L., and Godt, J. W. (2010). Early warning of rainfall-induced shallow landslides and debris flows in the USA. Landslides 7, 259-272. doi: 10.1007/s10346-009-0177-0

Bazin, S. (2012). Guidelines for landslide monitoring and early warning systems in Europe - Design and required technology, Project SafeLand "Living With Landslide Risk in Europe: Assessment, Effects of Global Change, and Risk Management Strategies". Deliverable 4.8, 153 pp. Available online at: https:// www.ngi.no/eng/Projects/SafeLand (Accessed May 7, 2018).

Bhatt, B. P., Awasthi, K. D., Heyojoo, B. P., Silwal, T., and Kafle, G. (2013). Using geographic information system and analytical hierarchy process in landslide hazard zonation. Appl. Ecol. Environ. Sci. 1, 14-22. doi: 10.12691/ aees-1-2-1

Calvello, M. (2017). Early warning strategies to cope with landslide risk. Rivista Ital. Geotec. 2, 63-91, doi: 10.19199/2017.2.0557-1405.063

Cruden, D. M., and Varnes, D. J. (1996). Landslide types and processes. Landslides: Investigation and Mitigation. Special Report 247, Transportation Research Board, Washington, 36-75.

Devoli, G., Tiranti, D., Cremonini, R., Sund, M., and Bøje, S. (2018). Comparison of landslide forecasting services in Piemonte (Italy) and in Norway, illustrated by events in late spring 2013. Nat. Hazards Earth Syst. Sci. 18, 1351-1372. doi: 10.5194/nhess-18-1351-2018

Fell, R. (1994). Landslide risk assessment and acceptable risk. Can. Geotech. J. 31, 261-272. doi: 10.1139/t94-031 implemented for various types of natural hazards, including landslides. Overview and classification of existing landslide EWSs are presented in Thiebes et al. (2012), Bazin (2012), Stähli et al. (2015), Devoli et al. (2018), and Segoni et al. (2018). In this research topic, a methodology to couple rainfall thresholds and susceptibility maps for hazard assessment at a regional scale is presented by Segoni et al.: this new approach has been tested in northern Tuscany (central Italy) where an appropriate calibration and validation of the hazard matrix has been implemented to meet stakeholder requirements. The availability of quantitative precipitation estimates (QPEs) based on weather radars with high spatial and temporal resolution provides new chances for automatic EWSs: Cremonini and Tiranti illustrate a successful application of an operational EWS in northern Italy. On November 2016, heavy rain hit Piemonte (north-western Italy), causing diffuse landslides and floods: the operational landslide EWS successfully detected the conditions for rainfall-induced landslides.

This Research Topic presents some original research papers on scientific studies representing an updated overview of recent achievements in slope processes research. The presented researches advance our understanding of landslide related hazards and the necessary mitigation actions. These papers also address the possible impacts of climate change on this significant natural hazard.

\section{AUTHOR CONTRIBUTIONS}

DT and RC present a sintesys of the state of the art about landslide hazard in the world and introduce the contributions collected in the Research Topic. Both authors listed have made substantial, direct and intellectual contribution to the work, and approved it for publication.
Fuchs, S., Kaitna, R., Scheidl, C., and Hübl, J. (2008). The Application of the Risk Concept to Debris Flow Hazards. Geomechanics and Tunnelling. Vol. 1; Berlin: Ernst \& Sohn Verlag für Architektur und technische Wissenschaften GmbH \& Co. KG, 120-129.

Gariano, S. L., and Guzzetti, F. (2016). Landslides in a changing climate. Earth Sci. Rev. 162, 227-252. doi: 10.1016/j.earscirev.2016.08.011

Glade, T. (2005). Linking debris-flow hazard assessment with geomorphology. Geomorphology 66, 189-213. doi: 10.1016/j.geomorph.2004.09.023

Havenith, H. B., Torgoev, A., Braun, A., Schlögel, R., and Micu, M. (2016). A new classification of earthquake-induced landslide event sizes based on seismotectonic, topographic, climatic and geologic factors. Geoenviron. Disasters 3, 1-24. doi: 10.1186/s40677-016-0041-1

Hungr, O., Leroueil, S., and Picarelli, L. (2014). The Varnes classification of landslide types, an update. Landslides 11, 167-194. doi: 10.1007/s10346-013-0436-y

Hungr, O., Morgan, G. C., and Kellerhals, R. (1984). Quantitative analysis of debris torrent hazard for design of remedial measures. Can. Geotech. J. 21, 663-677. doi: 10.1139/t84-073

Katsura, S., Kosugi, K., Mizutani, T., Okunaka, S., and Mizuyama, T. (2008). Effects of bedrock groundwater on spatial and temporal variations in soil mantle groundwater in a steep granitic headwater catchment. Water Resour. Res. 44:W09430. doi: 10.1029/2007WR006610

OFDA/CRED (2018). International Disaster Database. Brussels: Université Catholique de Louvain. Available online at: www.emdat.be (Accessed August 9, 2018). 
Pardeshi, S. D., Autade, S. E., and Pardeshi, S. S. (2013). Landslide hazard assessment: recent trends and techniques. Springerplus 2:523. doi: 10.1186/2193-1801-2-523

Rodríguez, C. E., Bommer, J. J., and Chandler, R. J. (1999). Earthquake induced landslides: 1980-1997. Soil Dyn. Earthq. Eng. 18, 325-346. doi: 10.1016/S0267-7261(99)00012-3

Segoni, S., Piciullo, L., and Gariano, S. L. (2018). A review of the recent literature on rainfall thresholds for landslide occurrence. Landslides 15, 1483-1501. doi: 10.1007/s10346-018-0966-4

Seneviratne, S. I., Nicholls, N., Easterling, D., Goodess, C. M., Kanae, S., Kossin, J., et al. (2012). "Changes in climate extremes and their impacts on the natural physical environment," in Managing the Risks of Extreme Events and Disasters to Advance Climate Change Adaptation. A Special Report of Working Groups I and II of the Intergovernmental Panel on Climate Change (IPCC), eds C. B. Field, V. Barros, T. F. Stocker, D. Qin, D. J. Dokken, K. L. Ebi, M. D. Mastrandrea, K. J. Mach, G.-K. Plattner, S. K. Allen, M. Tignor, and P. M. Midgley (Cambridge; New York, NY: Cambridge University Press), 109-230.

Stähli, M., Sättele, M., Huggel, C., McArdell, B. W., Lehmann, P., Van Herwijnen, A., et al. (2015). Monitoring and prediction in early warning systems for rapid mass movements. Nat. Hazards Earth Syst. Sci. 15, 905-917. doi: 10.5194/nhess-15-905-2015
Stoffel, M., Tiranti, D., and Huggel, C. (2014). Climate change impacts on mass movements - case studies from the European Alps. Sci. Total Environ. 493, 1255-1266. doi: 10.1016/j.scitotenv.2014. 02.102

Thiebes, B., Glade, T., and Bell, R. (2012). "Landslide analysis and integrative early warning-local and regional case studies," in Proceeding 11th International Symposium on Landslides (Banff, AB: CRC Press), 1915-1921.

UNISDR (2009). UNISDR - ISDR: Terminology. Available online at: http:// www.unisdr.org/eng/library/lib-terminology-enghome.htm (Accessed August 8, 2018).

Conflict of Interest Statement: The authors declare that the research was conducted in the absence of any commercial or financial relationships that could be construed as a potential conflict of interest.

Copyright () 2019 Tiranti and Cremonini. This is an open-access article distributed under the terms of the Creative Commons Attribution License (CC BY). The use, distribution or reproduction in other forums is permitted, provided the original author(s) and the copyright owner(s) are credited and that the original publication in this journal is cited, in accordance with accepted academic practice. No use, distribution or reproduction is permitted which does not comply with these terms. 